\title{
Energy and protein intake of older residents in private nursing homes in Finland
}

\section{Abstract}

Introduction: Malnutrition, low body mass index (BMI), and nutritional problems are common among nursing home residents. Quality of care including nutrition in long term care has been criticised lately. Objective was to study nutrition of older residents in private nursing homes in Finland for preparation of the upcoming intervention study.

Methods: Descriptive, cross-sectional study. Nutritional value of the menu used in nursing homes was evaluated. Food service personal and nurses had instructions to modify offered food suitable to different needs of residents. The residents' food intake for one day was assessed with food records and their energy and protein intakes were calculated. Nurses filled the food records and they were advised to include all kind of eaters. Information was also gathered about residents' weight, BMI, texture of the diet (normal, soft, mashed and smooth mashed) and their need for help in eating.

Results: Residents, $\mathrm{n}=161,57 \%$ female, mean age 81.0 y (SD \pm 11.1$)$ in 70 different nursing homes took part to the study. Their mean BMI was 24.6. (SD \pm 5.0 ), ranging from 15.0 to 45.0. The residents had five meals: breakfast, lunch, coffee, dinner and evening snack. Of the residents $68.3 \%$ had normal, $9.3 \%$ soft, $5.0 \%$ mashed and $14.3 \%$ smooth smashed texture in their food. Using average portion size it was possible to receive enough energy and protein daily. Residents' mean intake of energy was $1723 \mathrm{kcal}$ (SD \pm 506 ), ranging from $329 \mathrm{kcal}$ to $3167 \mathrm{kcal}$ per day, mean intake of protein was $69 \mathrm{~g}(\mathrm{SD} \pm 24)$, ranging from $14 \mathrm{~g}$ to $141 \mathrm{~g}$ per day. When protein intake was calculated by $\mathrm{g} / \mathrm{kg}$ BW/day, the mean intake was $1.0 \mathrm{~g}$ (SD \pm 0.34 ), ranging from 0.2 to $2 \mathrm{~g} / \mathrm{kg} \mathrm{BW} / \mathrm{day}$. Female residents had lower energy intake $(1557 \mathrm{kcal}, \mathrm{SD} \pm 486)$ than male $(1888 \mathrm{kcal}, \mathrm{SD} \pm 450), \mathrm{p}<0.001$ and protein intake $(\mathrm{F} 62 \mathrm{~g}, \mathrm{SD} \pm 22) /(\mathrm{M} 72$ $\mathrm{g}, \mathrm{SD} \pm 24), \mathrm{p}<0.001$ but not when counting $\mathrm{g} / \mathrm{kg} \mathrm{BW} /$ day.

Discussion: Nutritional value of the menu in average met the recommendations for older people's nutrition. Although the mean intakes of energy and protein were adequate there was a great variation in intakes and a part of the residents received so little energy and protein that it would evidently lead to malnutrition. Taking account the wide range of residents' BMI, energy and protein intake education of the personnel in personalized nutrition is needed.

\section{Conflict of Interest}

There is no conflict of interest 